\title{
nature
}

21 June 2001 Volume 411 Issue no 6840

\section{Storm clouds over Brussels}

Europe's research commissioner should develop a bolder vision for his 'European Research Area', while explicitly addressing the conflicting demands on the European Union's research programme.

n January 2000, just a few months after taking over as European Commissioner for Research, Philippe Busquin floated his big idea - the European Research Area (ERA). The goal was to create a coherent European science policy, including unfettered mobility of researchers and support at the European Union (EU) level for largescale research infrastructure.

Eighteen months later, there are fears that Busquin may have overreached himself. Many observers cannot see how this ambitious goal will be met, particularly given the questions that now hang over the centre-piece of Busquin's plans, the sixth five-year Framework programme for research, due to start in 2003.

The document that launched the ERA noted that it could not be created through the Framework programmes alone. But the disquiet surrounding Busquin's proposal for the sixth Framework bodes ill for his wider vision. The plan will be discussed next week by ministers from the member states, chaired by Thomas Östros, Sweden's science minister. Ominously, Östros has talked of "major question marks".

Östros is worried about support for basic and long-term research, which he feels are undervalued in Busquin's proposal. He also doubts whether procedures for selecting projects - and for monitoring grant-holders - are strong enough to guarantee scientific quality.

Later this year, the proposal will be debated by the European Parliament, whose members have begun to call for numerous changes. Some want to strengthen non-nuclear energy research, others want to streamline application procedures further, while others desire a merger between the 'genomics and biotechnology for health' and the 'food safety and health risks' programmes.

Busquin's fundamental problem is that Framework serves a multitude of masters with divergent demands. Leading scientific EU nations, for instance, are pleased with plans to support fewer, larger projects and delegate much of the management to the labs involved. But the Eastern and Central European nations queuing up to join the EU — and who already participate in Framework — complain that this will cut them out of the picture (see Nature 411, 512; 2001). Successful integration of these nations, meanwhile, is a major component of the ERA proposal.

Although Busquin's task is not easy, he can be criticized for failing to balance long-term goals and political realities. His wholesale shift of EU funding into larger projects and support for infrastructure makes some sense in the context of the ERA. But many voices from the grassroots have made it clear that they want more continuity and the retention of some of the familiar small-scale research networks funded under the current Framework programme.

Busquin is also open to charges of vagueness. The ERA proposal, for instance, called for EU support for projects with "variable geometry" - bilateral and multilateral collaborations initiated by the member states. Such funding would be allowed under Busquin's sixth Framework proposal. But few policymakers or scientists have a clear idea of what this would mean in practice — and this uncertainty is breeding misgivings.

Although delays are likely, it is not too late for Busquin to work with Europe's research ministers and the parliament to make the sixth Framework more attractive to the best scientists across the continent. In parallel, he should begin planning the concrete moves needed to make the ERA a reality.

In the long run, however, the ERA is likely to remain a bloodless vision unless there is an independent, flexible and self-administered pan-European funding body which - unlike the ponderous Framework - can react quickly to unexpected scientific developments.

A possible starting point exists. The European Coal and Steel Community - which created a 'common market' that eventually became subsumed within the EU - will be converted next year into a research fund for the coal and steel industries, endowed with some 1.3 billion euros (US $\$ 1.1$ billion). If European law were changed to allow this body to be boosted with further private and public money, it might eventuallybe transformed into a true pan-European research foundation.

\section{Some advice for the president}

\section{George W. Bush needs a scientific adviser even more than the US research community needs a voice in the White House.}

$\mathrm{T}$ he two issues that so deeply divided the United States and Europe during President George W. Bush's transatlantic visit last week have this much in common: for both global warming and missile defence, governments need to interpret complex scientific arguments before deciding on a particular course of action.

It is doubly unfortunate, therefore, that Bush went to Europe without a scientific adviser by his side - or even at the end of the phone. Some five months into his administration, the position of the president's special assistant on science and technology, who also runs the White House Office of Science and Technology Policy (OSTP), remains unfilled.

Bill Clinton took just four days to name Jack Gibbons as candidate for the position after his January 1993 inauguration. Bush cannot be judged by that standard: after all, the planning of his administration was delayed by the lengthy dispute over his election last November. But with scientific issues now having more bearing than ever on practical politics, the current delay is eating away at the credibility of Bush's positions on missile defence, climate change, energy policy and stem-cell research. It is also eroding the prospect that the OSTP will ever become fully staffed and functional under the Bush administration: other branches of the White House are greedy for its staff slots, and may soon borrow some of them.

Meanwhile, Bush's critics in the US scientific community - who are not entirely without influence on public opinion - are left to fulminate from the outside over the president's various policy positions. The sooner Bush appoints a respected Republican scientist to head the OSTP, the better are his chances of avoiding embarrassment in forthcoming debates on these positions. 